\title{
Pemetaan Wilayah Lahan Basah Berdasarkan Data Penginderaan Jauh Optik Dan Radar
}

\author{
Rian Nurtyawan, Ervan Muktamar Hendarna \\ Jurusan Teknik Geodesi, Fakultas Teknik Sipil dan Perencanaan, ITENAS, Bandung \\ Email: nurtyawan70@gmail.com; ehendarna@gmail.com
}

Received 30 Maret 2020 | Revised 22 Juni 2020 | Accepted 03 Juli 2020

\begin{abstract}
ABSTRAK
Pada umumnya lahan basah dikelola menjadi area pertanian ataupun perkebunan. Fungsi lahan basah memiliki fungsi ekologis seperti pengendali banjir, pencegah intrusi air laut, erosi, pencemaran, dan pengendali iklim global. Data pengindraan jauh yang digunakan pengelolaan lahan basah yaitu pengindraan jauh optik dan radar. Tujuan dari penelitian ini adalah mengeksplorasi korelasi potensial dari data optik dan radar untuk mengamati dinamika pada kawasan lahan basah tersebut dan melakukan pemetaan. Metode yang digunakan pada pengindraan jauh optik yaitu LST (Land Surface Temperature) berdasarkan Citra Satelit Landsat-8 dan metode yang digunakan pada pengindraan jauh radar yaitu estimasi kelembaban tanah berdasarkan Citra Satelit Sentinel-1A. Hasil pengamatan dinamika dan pemetaan pada wilayah Kabupaten Bandung Raya memiliki nilai kelembaban tanah tertinggi pada Bulan Mei dengan nilai kelembapan tanah tanah rata-rata sebesar 20,9\% pada polarisasi VH. Suhu permukaan tanah terendah terjadi pada bulan Mei dengan nilai suhu rata-rata sebesar $19.5{ }^{\circ} \mathrm{C}$. Kolerasi antara nilai kelembapan tanah tanah dan suhu permukaan tanah pada wilayah Kabupaten Bandung Raya berdasarkan metode koefisien determinasi sebesar $R^{2}=0.705$ didapatkan bahwa semakin tinggi nilai kelembapan tanah tanah maka nilai suhu permukaan tanah akan semakin rendah.
\end{abstract}

Kata kunci: Kawasan lahan basah, Pengindraan Jauh Optik, Pengindraan Jauh Radar, Pengamatan Dinamika, Pemetaan.

\begin{abstract}
In general wetlands managed become an area of agriculture or plantations. The extent of wetland that has been used can be damaged if it is not managed properly and integrated. The purpose of this research is to explore the potential correlations between several parameters of optical and radar data to observe the dynamics of wetlands area and mapping the wetlands area. The methodology that was used in optical remote sensing is LST (Land Surface Temperature) based on Landsat-8 Satellite Image and the method used in remote radar sensing is estimation of soil moisture based on Sentinel-1A Satellite Image. The result of the observation in the area and mapping the dynamics in Bandung Raya District had the highest soil moisture values in May with 27\% of soil water level in VH polarization and $78.1 \%$ in VV polarization and the lowest value in each month is $11.8 \%$ and the highest soil surface temperature in August with a value $37.9^{\circ} \mathrm{C}$ and the minimum value $19^{\circ} \mathrm{C}$.
\end{abstract}

Keywords: Wetland Area, Optical Remote Sensing, Remote Radar Sensing, Dynamics Observation, Mapping. 


\section{PENDAHULUAN}

Luas lahan basah di Indonesia diperkirakan 20,6 juta ha atau sekitar 10,8 \% dari luas daratan Indonesia [1]. Pada umumnya lahan basah dikelola menjadi area pertanian ataupun perkebunan. Sebagian besar lahan basah dimanfaatkan masyarakat untuk budi daya tanaman perkebunan seperti kelapa sawit, karet, disusul tanaman pangan meliputi padi, jagung, selanjutnya tanaman buah [2]. Sekitar 9,53 juta lahan basah di Indonesia berpotensi untuk lahan pertanian, dengan rincian 6 juta ha berpotensi untuk tanaman pangan dan 4,186 juta ha telah direklamasi untuk berbagai penggunaan terutama transmigrasi [3]. Luasnya lahan basah yang telah dimanfaatkan sebagai lahan pertanian dan pemukiman menjadikan lahan ini dapat mengalami kerusakan jika tidak dikelola dengan tepat dan terpadu. Penggunaan lahan basah harus direncanakan dan dirancang secara cermat dengan asas tata guna lahan berperspektif jangka panjang [4].

Selama beberapa dekade terakhir, teknologi pengindraan jauh telah menjadi alat paling efektif untuk memperoleh data lahan basah temporal dan spasial, data pengindraan jauh telah digunakan di sejumlah daerah penelitian lahan basah [5]. Sebuah tinjauan terbaru tentang pengindraan jauh lahan basah menyatakan bahwa jumlah publikasi pengindraan jauh lahan basah telah meningkat secara drastis sejak tahun 1990-an [6]. Sensor pengamatan optik dan gelombang mikro dapat digunakan untuk memantau lahan basah; dengan demikian, satelit optik sebagian besar efektif dalam pemantauan vegetasi serta pemetaan perubahan lahan basah [7].

Teknologi Synthetic Aperture Radar (SAR) sangat efektif untuk memantau perubahan dalam lahan basah baik secara musiman maupun tahunan[8]. SAR memiliki banyak karakteristik yang membuatnya ideal untuk pemetaan dan pemantauan lahan basah seiring waktu. SAR mampu menangkap suatu wilayah yang dipetakan pada malam atau siang hari, melalui tutupan awan [9]. Selain itu, sifat lahan basah yang memiliki indeks sebaran air yang dapat ditransmisikan oleh data SAR. Hamburan gelombang mikro yang diterima oleh sensor SAR dari lahan basah adalah tergantung pada panjang gelombang, polarisasi, dan sudut datangnya energi yang ditransmisikan, sifat vegetasi dan tanah. Oleh karena itu, panjang gelombang SAR, polarisasi, dan incident angle harus dipilih dengan cermat untuk memaksimalkan hamburan untuk membedakan dari lahan basah dan untuk identifikasi lahan basah.

Tujuan dari penelitian ini adalah untuk mengeksplorasi korelasi potensial antara beberapa parameter dari data optik dan SAR untuk pemahaman yang lebih baik tentang dinamika lahan basah. Dengan melakukan pengamatan dinamika kawasan lahan basah di permukaan bumi dan dilakukannya pemetaan pada kawasan tersebut menggunakan teknik pengindraan jauh pada wilayah yang diamati menjadi lebih cepat. Sehingga dengan kawasan lahan basah tersebut dapat diketahui dan informasinya dapat digunakan secara praktis oleh instansi yang membutuhkan.

\section{METODOLOGI}

\subsection{Pengolahan Data Citra Satelit Landsat-8}

Pada pengolahan data Citra Satelit Landsat-8 menggunakan metode LST (Land Surface Temperature), untuk mendapatkan nilai LST terdapat rumus yang dapat digunakan pada Persamaan 1.

$$
T_{S}=\frac{B T}{\left\{1+\left[\frac{\lambda B T}{\rho} \ln \varepsilon \lambda\right]\right\}}
$$

Keterangan:

Ts

BT

$\lambda$

$\rho$
: Land Surface Temperature

: Brightness Temperature

: Panjang gelombang dipancarkan

: Konstanta 
Pada metode ini terdapat langkah-langkah dimulai Konversi Top of Atmospheric (TOA) Spectral Radiance, Konversi At-Sensor Temperature, NDVI (Normalized Difference Vegetation Index), Menghitung proporsi vegetasi (Pv), Penetapan terhadap emisivitas tanah, dan Hitungan nilai LST [10].

\subsection{Pengolahan Data Citra Satelit Sentinel-1A}

Pada pengolahan data Citra Satelit Sentinel-1A menggunakan metode estimasi kelembaban tanah, untuk mendapatkan nilai kelembaban tanah terdapat model polinomial yang dapat digunakan pada Persamaan 2.

$$
m_{v}=-5.3 \times 10^{-2}+2.29 \times 10^{-2} \varepsilon^{\prime}-5.5 \times 10^{-4} \varepsilon^{\prime-2}+4.3 \times 10^{-6} \varepsilon^{\prime-3}
$$

Keterangan:

$m_{v} \quad:$ Kelembapan tanah tanah (\%).

$\varepsilon^{\prime} \quad$ : Konstanta dielektrik

Metode ini terdapat langkah-langkah dimulai kalibrasi radiometrik, multilooking, speckle reducing, koreksi geometrik, $d B$ Conversion, konstanta dielektrik dan hitungan nilai estimasi kelembaban tanah.

\subsection{Data Penelitian}

Penelitian ini memerlukan peralatan yang dipersiapkan meliputi perangkat lunak yaitu ArcGIS 10.3 dan SNAP 6.0, digunakan pada tahap pengolahan data hingga penyajian data. Data yang digunakan dalam penelitian ini dapat dilihat pada Tabel 1.

Tabel 1. Data Penelitian

\begin{tabular}{|c|c|c|c|c|}
\hline No & Jenis Data & Tahun & Spesifikasi Data & Sumber \\
\hline 1 & $\begin{array}{l}\text { Citra Satelit } \\
\text { Sentinel-1A }\end{array}$ & 2018 & $\begin{array}{l}\text { 1. Sensor Radar } \\
\text { 2. Resolusi Spasial } 5 \mathrm{~m} \text { x } 20 \\
\mathrm{~m} \\
\text { 3. Resolusi Temporal } 1 \text { bulan }\end{array}$ & scihub.copernicus.eu/ \\
\hline 2 & $\begin{array}{l}\text { Citra Satelit } \\
\text { Landsat- } 8\end{array}$ & 2018 & $\begin{array}{l}\text { 1. Sensor Optik } \\
\text { 2. Resolusi Spasial } 30 \mathrm{~m} \\
\text { 3. Resolusi Temporal } 1 \text { bulan }\end{array}$ & earthexplorer.usgs.gov \\
\hline 3 & $\begin{array}{c}\text { Batas } \\
\text { Administrasi }\end{array}$ & 2018 & $\begin{array}{l}\text { 1. Skala 1:250.000 } \\
\text { 2. Format Shapefile }\end{array}$ & $\begin{array}{c}\text { Dinas Kehutanan Provinsi } \\
\text { Jawa Barat }\end{array}$ \\
\hline
\end{tabular}

Analisis data yang digunakan merupakan citra Landsat-8 dan Sentinel-1A pada tahun 2018 dan pada musim yang diambil pada data citra merupakan musim kemarau (bulan April, Mei, Juni, Juli, dan Agustus). Data citra yang digunakan dapat dilihat pada Tabel 1.

\subsection{Metode Pengolahan Data}

Metode pengolahan data yang digunakan untuk mengolah data Citra Satelit Landsat-8 dan Citra Satelit Sentinel 1-A dan data lainnya untuk menghitung pengamatan dinamika dan pemetaan kawasan lahan basah dilakukan seperti pada diagram alir seperti yang ditunjukan pada Gambar 1 . 


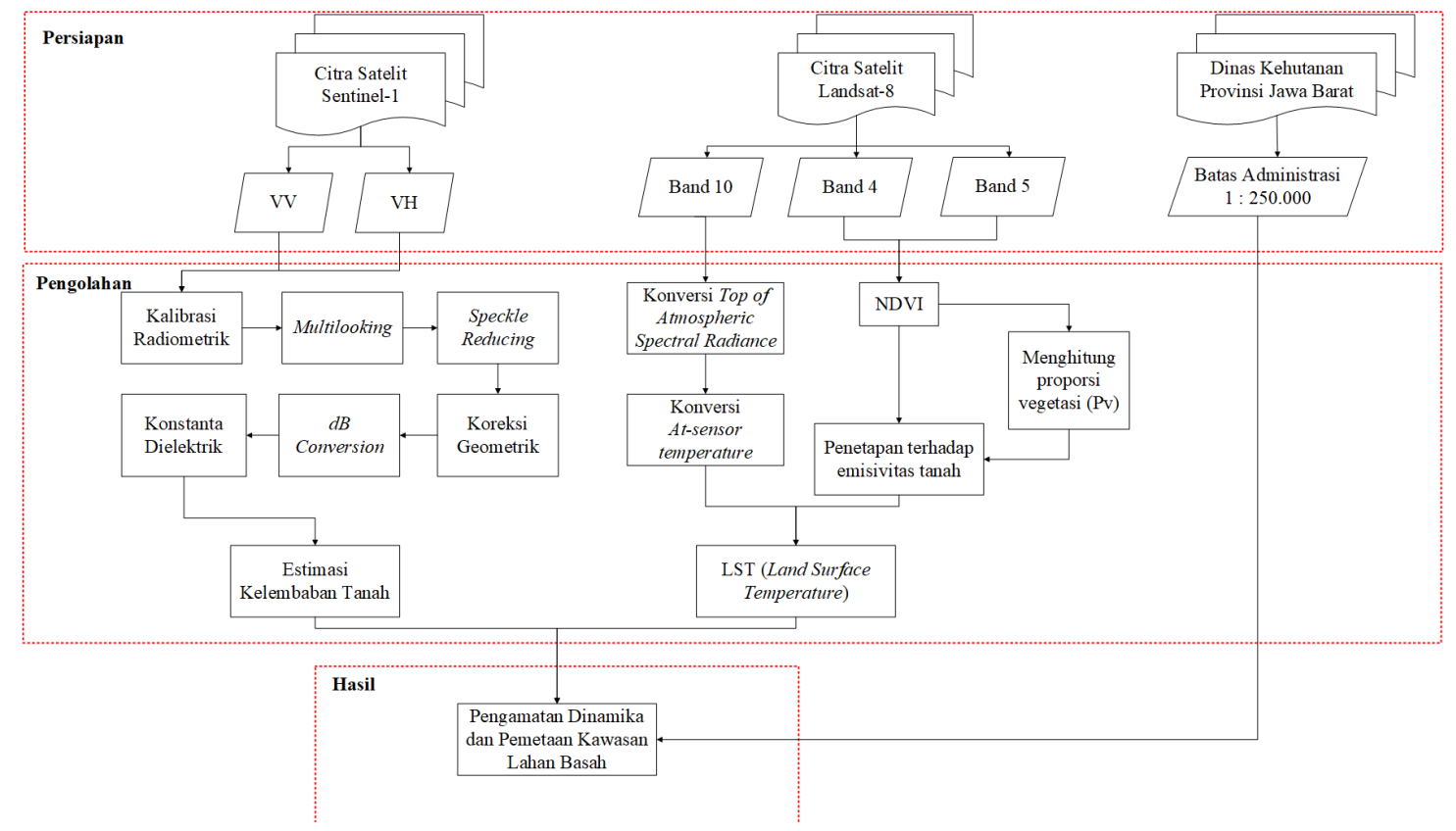

Gambar 1. Diagram alir pengolahan data

Pengolahan data dilakukan sebagai berikut:

1. Tahap persiapan penting dilakukan untuk menunjang keberhasilan pelaksanaan penelitian agar pelaksanaan penelitiaan berjalan sesuai harapan. Tahapan ini terdiri dari administrasi serta perangkat lunak untuk pengambilan dan pengolahan data.

2. Lokasi penelitian ini berada di Kabupaten Bandung Provinsi Jawa Barat yang terletak pada $107^{\circ} 22^{\prime}$ - $108^{\circ} 5^{\prime}$ BT dan $6^{\circ} 41^{\prime}-7^{\circ} 19^{\prime}$ LS seperti yang ditujukan pada Gambar 2.

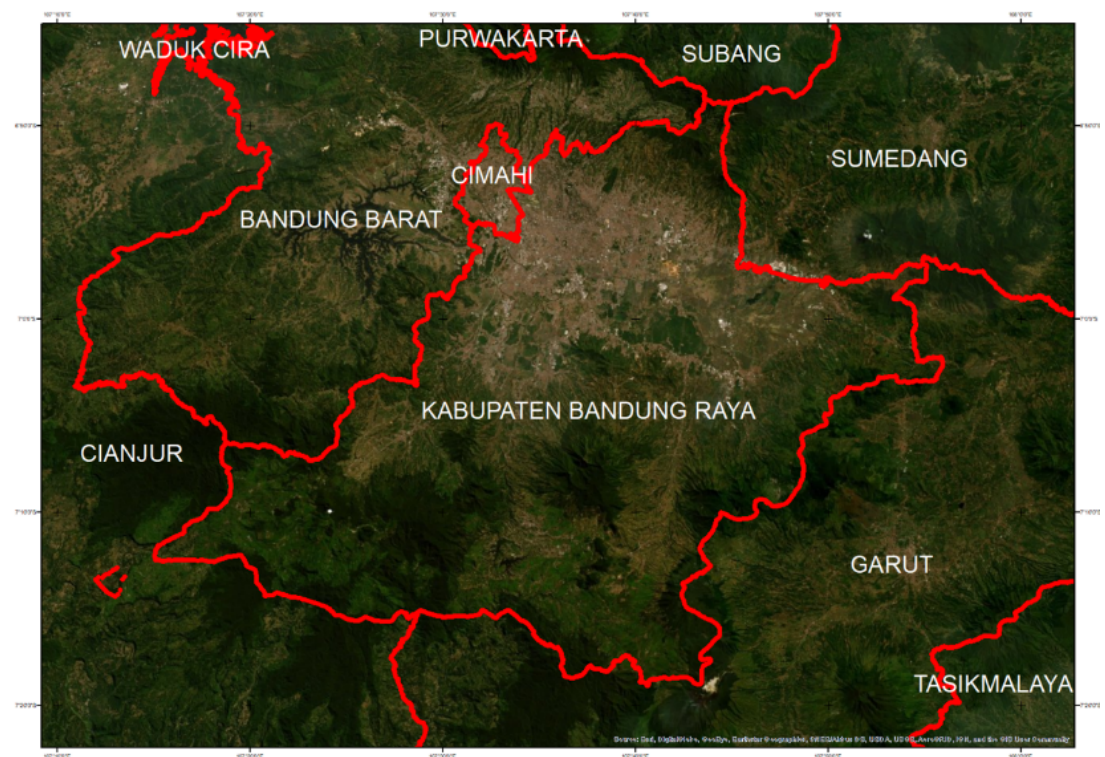

Gambar 2. Lokasi Penelitian

3. Pengolahan data dalam penelitian pengamatan dinamika dan pemetaan di Kabupaten Bandung terbagai menjadi dua, yaitu tahapan pengolahan data Citra Satelit Sentinel-1A dan Citra Satelit Landsat-8.

4. Pada pengolahan data Citra Satelit Landsat-8 menggunakan metode LST (Land Surface Temperature), Pada metode ini terdapat langkah-langkah dimulai Konversi Top of Atmospheric 
(TOA) Spectral Radiance, Konversi At-Sensor Temperature, NDVI (Normalized Difference Vegetation Index), Menghitung proporsi vegetasi ( $\mathrm{Pv})$, Penetapan terhadap emisivitas tanah, dan Hitungan nilai LST

5. Pada pengolahan data Citra Satelit Sentinel-1A menggunakan metode estimasi kelembaban tanah, untuk mendapatkan nilai kelembaban tanah terdapat model polynomial, Metode ini terdapat langkahlangkah dimulai kalibrasi radiometrik, multilooking, speckle reducing, koreksi geometrik, $d B$ Conversion, konstanta dielektrik dan hitungan nilai estimasi kelembaban tanah.

\section{HASIL DAN PEMBAHASAN}

Pemetaan kawasan lahan basah menggunakan teknologi pengindraan jauh optik yaitu Citra Satelit Landsat 8 dan pengindraan jauh radar yaitu Citra Satelit Sentinel-1A dengan pengamatan dinamika berdasarkan parameter bulan April, Mei, Juni, Juli, Agustus tahun 2018 pada masing-masing citra satelit.

Wilayah kabupaten bandung di klasifikasi menjadi 5 (lima) kecamatan yang dilakukan pengolahan estimasi kelembaban tanah dan suhu permukaan tanah yaitu Kecamatan Bojongsoang, Bumiwangi, Mekarsari, Wanasari, dan Wargaluyu seperti yang ditunkukan pada Gambar 3.

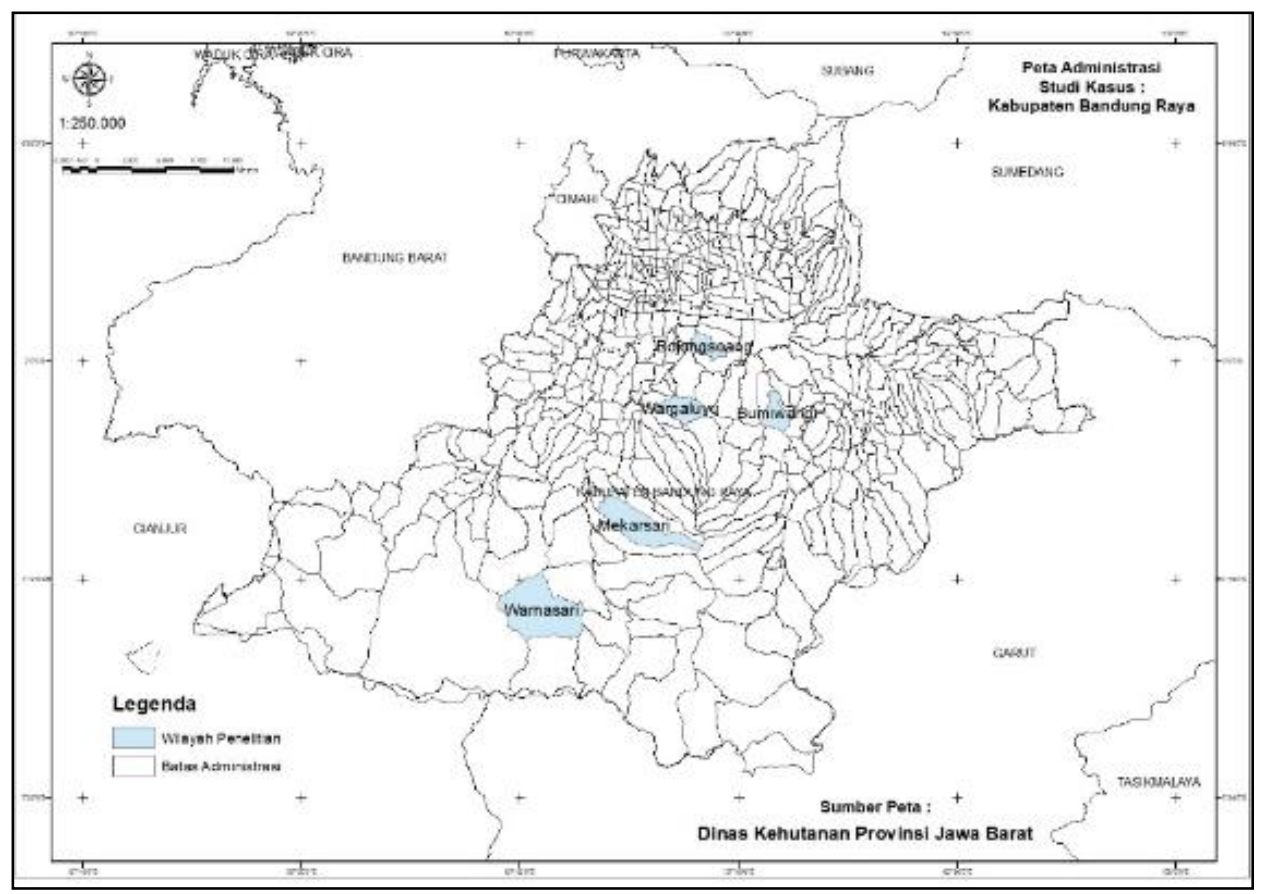

Gambar 3. Peta Administrasi Kabupaten Bandung Raya

\subsection{Pemetan Kelembaban Tanah}

Hasil pemetaan nilai kelembaban di Kabupaten Bandung Raya pada bulan April - Agustus Tahun 2018 yang mengalami nilai Kelembaban tertinggi terjadi pada bulan Mei dengan nilai kelembaban $27 \%$ dan nilai minimum pada setiap bulan memiliki nilai sama yaitu $11,8 \%$ seperti yang ditunjukan pada Gambar 4. 


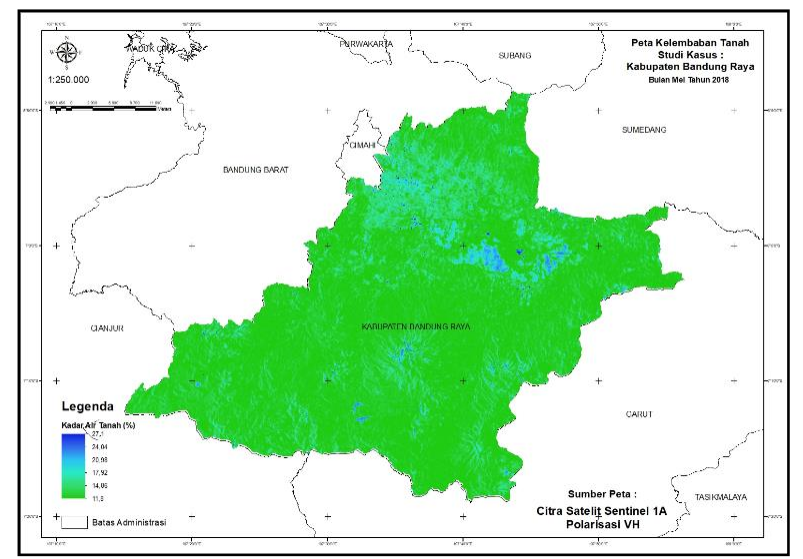

\section{Gambar 4. Peta Kelembaban Tanah Kabupaten Bandung Raya Bulan Mei Tahun 2018 Citra Satelit} Sentinel-1A Polarisasi VH

Hasil pemetaan nilai kelembaban di Wilayah Bojongsoang, Kabupaten Bandung pada bulan April Agustus Tahun 2018 nilai Kelembaban tertinggi terjadi pada bulan Mei dengan nilai kelembaban 28,3 $\%$ dan nilai minimum pada setiap bulan memiliki nilai sama yaitu $11,8 \%$ seperti yang ditunjukan pada Gambar 5.

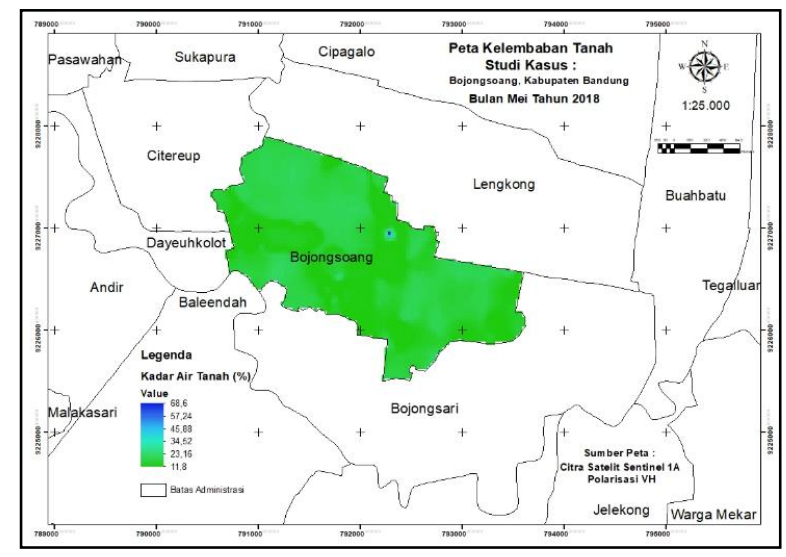

Gambar 5. Peta Kelembaban Tanah Bojongsoang, Kabupaten Bandung Raya Bulan Mei Tahun 2018 Citra Satelit Sentinel-1A Polarisasi VH

Hasil pemetaan nilai kelembaban di Wilayah Bumiwangi, Kabupaten Bandung pada bulan April Agustus Tahun 2018 nilai Kelembaban tertinggi terjadi pada bulan Juli dengan nilai kelembaban 23,7 $\%$ dan nilai minimum pada setiap bulan memiliki nilai sama yaitu $11,8 \%$ seperti yang ditunjukan pada Gambar 6. 


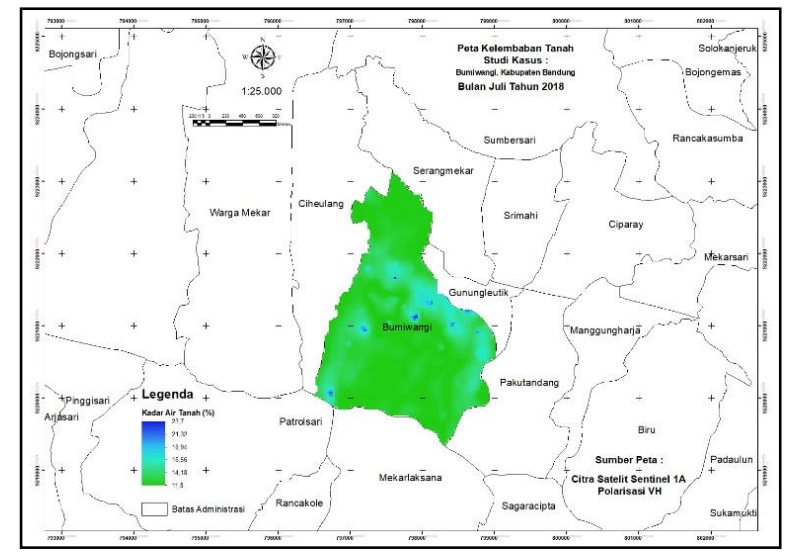

Gambar 6. Peta Kelembaban Tanah Bumiwangi, Kabupaten Bandung Raya Bulan Juli Tahun 2018 Citra Satelit Sentinel-1A Polarisasi VH

Hasil pemetaan nilai kelembaban di Wilayah Mekarsari, Kabupaten Bandung pada bulan April Agustus Tahun 2018 nilai Kelembaban tertinggi terjadi pada bulan Mei dan Juni dengan nilai kelembaban $26,9 \%$ dan nilai minimum pada setiap bulan memiliki nilai sama yaitu $11,8 \%$ seperti yang ditunjukan pada Gambar 7.

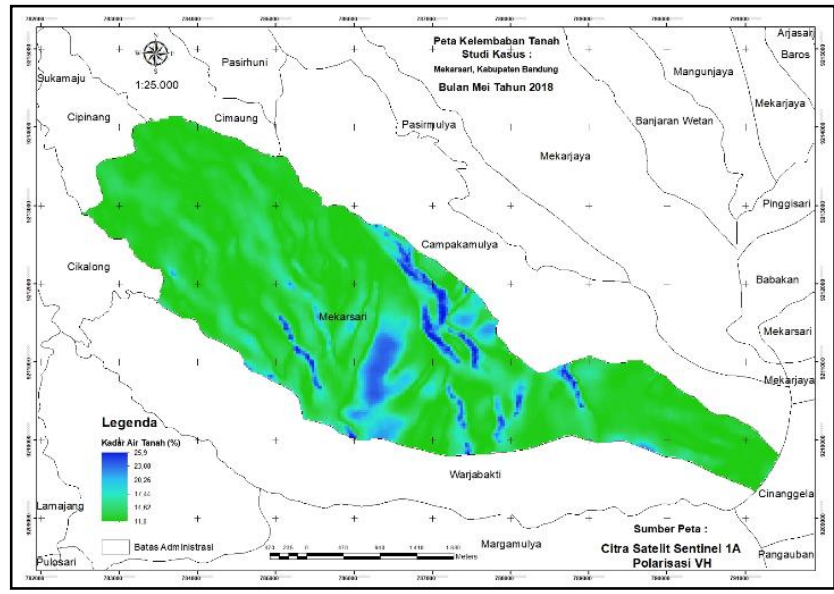

Gambar 7. Peta Kelembaban Tanah Mekarsari, Kabupaten Bandung Raya Bulan Mei Tahun 2018 Citra Satelit Sentinel-1A Polarisasi VH

Hasil pemetaan nilai kelembaban di Wilayah Wanasari, Kabupaten Bandung pada bulan April - Agustus Tahun 2018 nilai Kelembaban tertinggi terjadi pada bulan Agustus dengan nilai kelembaban 25,9\% dan nilai minimum pada setiap bulan memiliki nilai sama yaitu $11,8 \% \%$ seperti yang ditunjukan pada Gambar 8. 


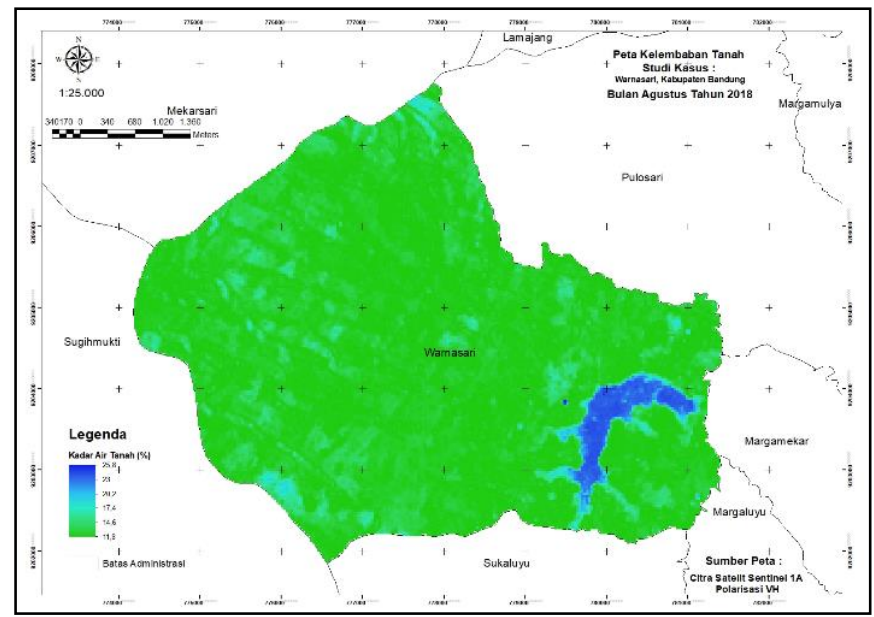

Gambar 8. Peta Kelembaban Tanah Wanasari, Kabupaten Bandung Raya Bulan Agustus Tahun 2018 Citra Satelit Sentinel-1A Polarisasi VH

Hasil pemetaan nilai kelembaban di Wilayah Wargaluyu, Kabupaten Bandung pada bulan April Agustus Tahun 2018 nilai Kelembaban tertinggi terjadi pada bulan Juni dengan nilai kelembaban 25,7 $\%$ dan nilai minimum pada setiap bulan memiliki nilai sama yaitu $11,8 \%$ seperti yang ditunjukan pada Gambar 9.

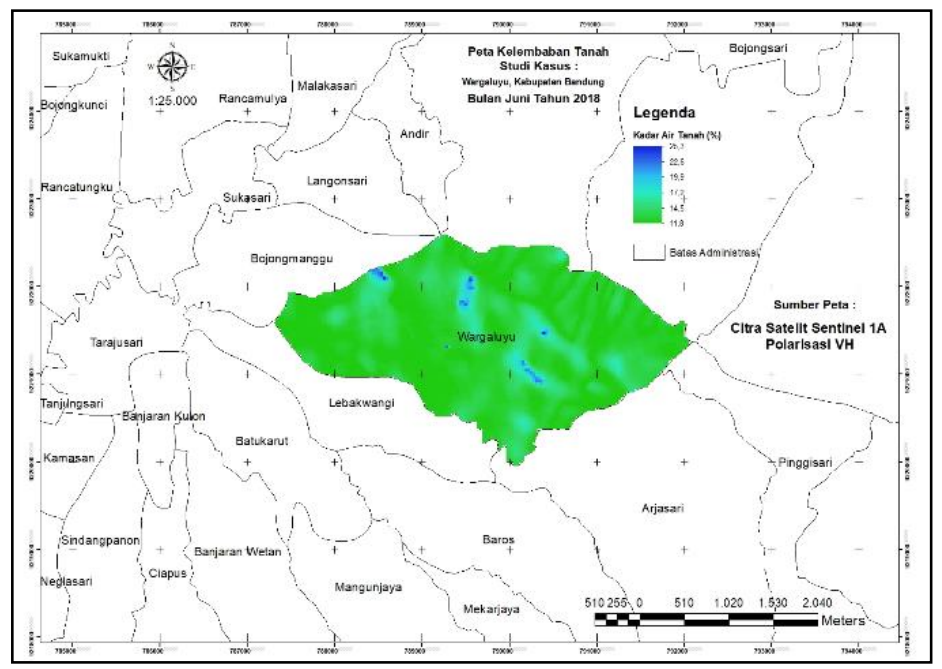

Gambar 9. Peta Kelembaban Tanah Wargaluyu, Kabupaten Bandung Raya Bulan Juni Tahun 2018 Citra Satelit Sentinel-1A Polarisasi VH

\subsection{Pemetan Suhu Permukaan}

Hasil pemetaan suhu permukaan tanah di Wilayah Kabupaten Bandung Raya pada bulan April - Agustus Tahun 2018 nilai suhu tertinggi terjadi pada bulan Agustus dengan nilai suhu $37,9^{\circ} \mathrm{C}$ dan nilai minimum pada setiap bulan memiliki nilai sama yaitu $19^{\circ} \mathrm{C}$ seperti yang ditunjukan pada Gambar 10 . 


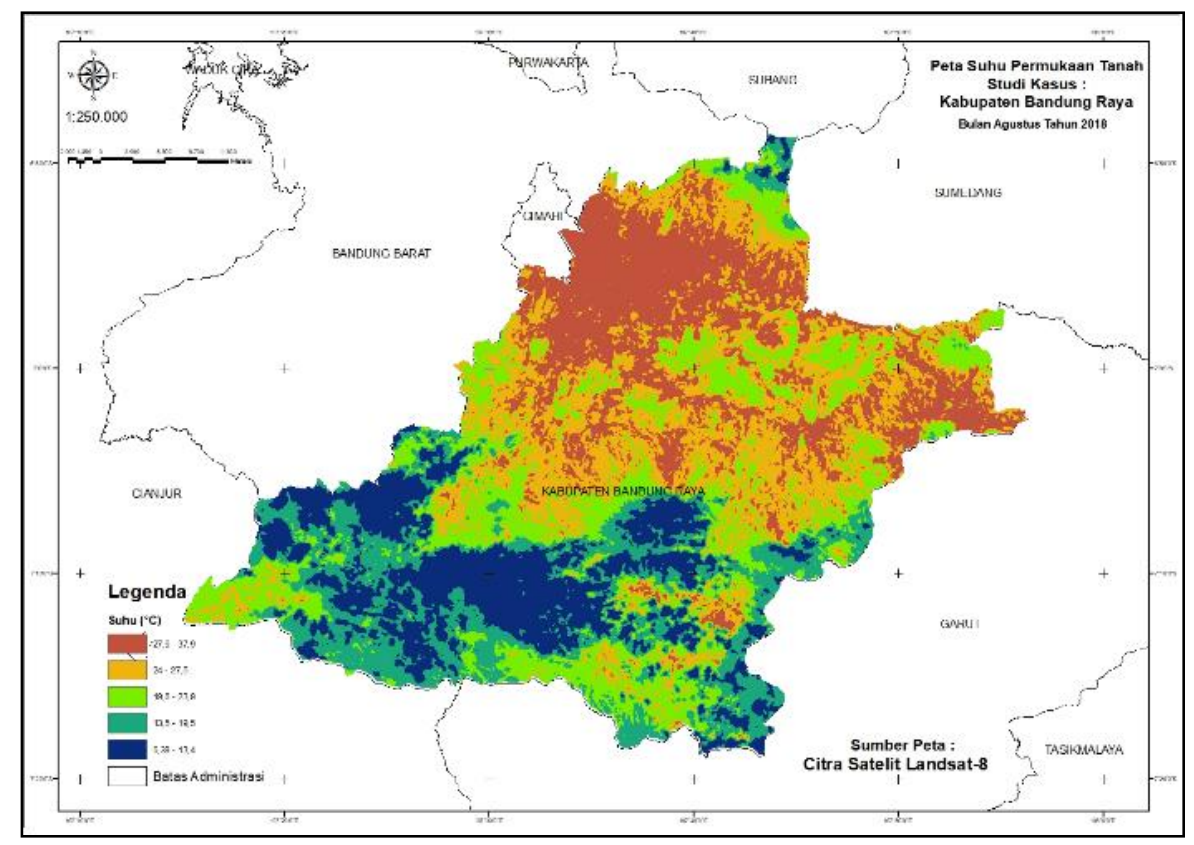

Gambar 10. Peta Suhu Permukaan Tanah Kabupaten Bandung Raya Bulan Agustus Tahun 2018 Citra Satelit Landsat-8

Hasil pemetaan suhu permukaan tanah di Wilayah Bojongsoang, Kabupaten Bandung pada bulan April - Agustus Tahun 2018 nilai suhu tertinggi terjadi pada bulan April dengan nilai suhu $30,8{ }^{\circ} \mathrm{C}$ dan nilai minimum dengan nilai $22,5^{\circ} \mathrm{C}$ seperti yang ditunjukan pada Gambar 11 .

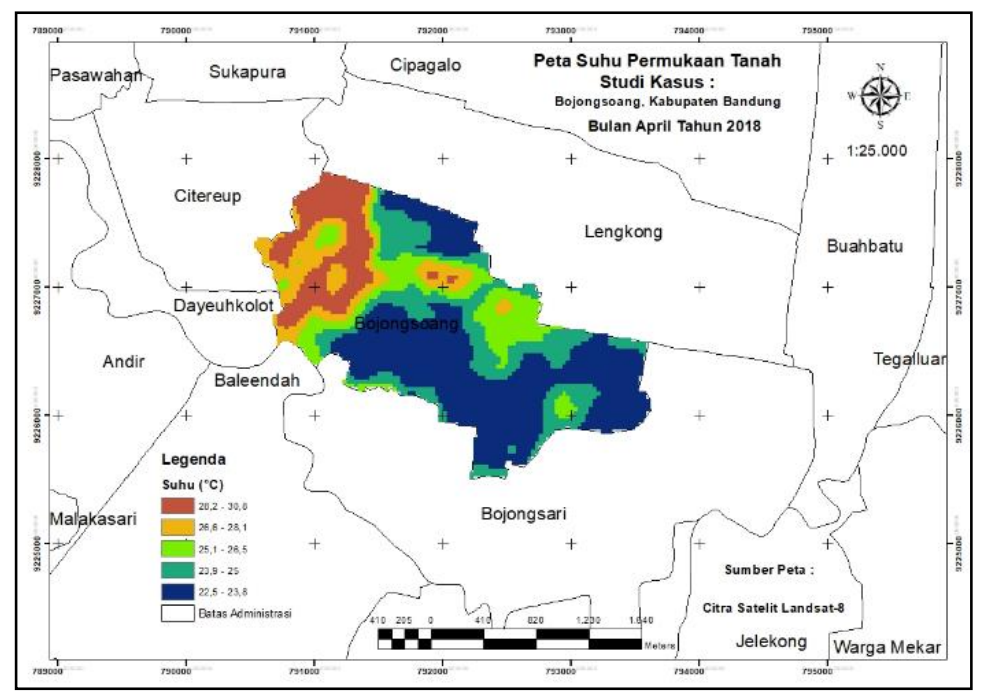

\section{Gambar 11. Peta Suhu Permukaan Tanah Bojongsoang, Kabupaten Bandung Raya Bulan April Tahun 2018 Citra Satelit Landsat-8}

Hasil pemetaan suhu permukaan tanah di Wilayah Bumiwangi, Kabupaten Bandung pada bulan April Agustus Tahun 2018 nilai suhu tertinggi terjadi pada bulan Agustus dengan nilai suhu $31,8^{\circ} \mathrm{C}$ dan nilai minimum dengan nilai $22,4{ }^{\circ} \mathrm{C}$ seperti yang ditunjukan pada Gambar 12 . 


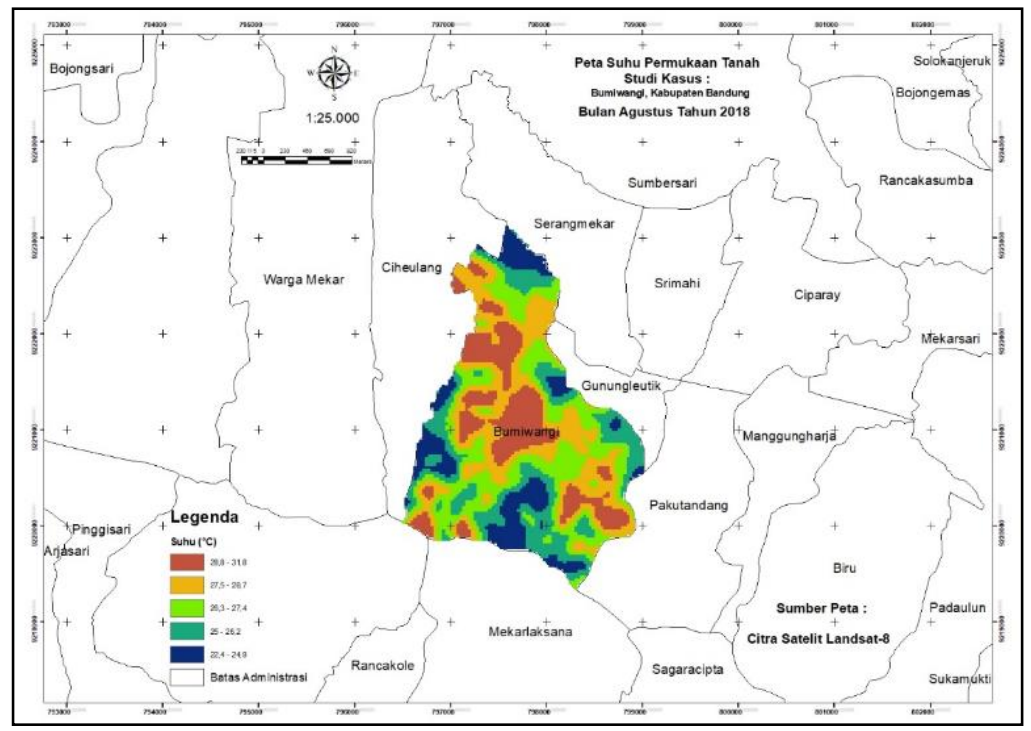

Gambar 12. Peta Suhu Permukaan Tanah Bumiwangi, Kabupaten Bandung Raya Bulan Agustus Tahun 2018 Citra Satelit Landsat-8

Hasil pemetaan suhu permukaan tanah di Wilayah Mekarsari, Kabupaten Bandung pada bulan April Agustus Tahun 2018 nilai suhu tertinggi terjadi pada bulan Agustus dengan nilai suhu $27,7^{\circ} \mathrm{C}$ dan nilai minimum dengan nilai $7,8^{\circ} \mathrm{C}$ seperti yang ditunjukan pada Gambar 13 .

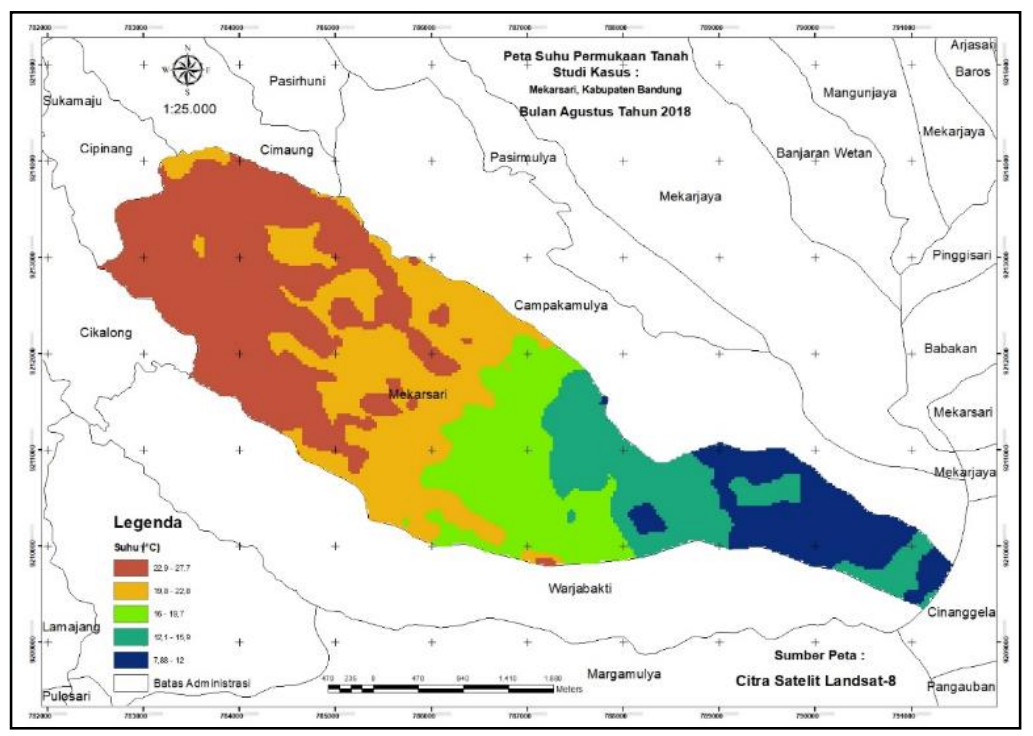

Gambar 13. Peta Suhu Permukaan Tanah Mekarsari, Kabupaten Bandung Raya Bulan Agustus Tahun 2018 Citra Satelit Landsat-8

Hasil pemetaan suhu permukaan tanah di Wilayah Warnasari, Kabupaten Bandung pada bulan April Agustus Tahun 2018 nilai suhu tertinggi terjadi pada bulan Juli dengan nilai suhu $29,5^{\circ} \mathrm{C}$ dan nilai minimum dengan nilai $16,2{ }^{\circ} \mathrm{C}$ seperti yang ditunjukan pada Gambar 14 . 


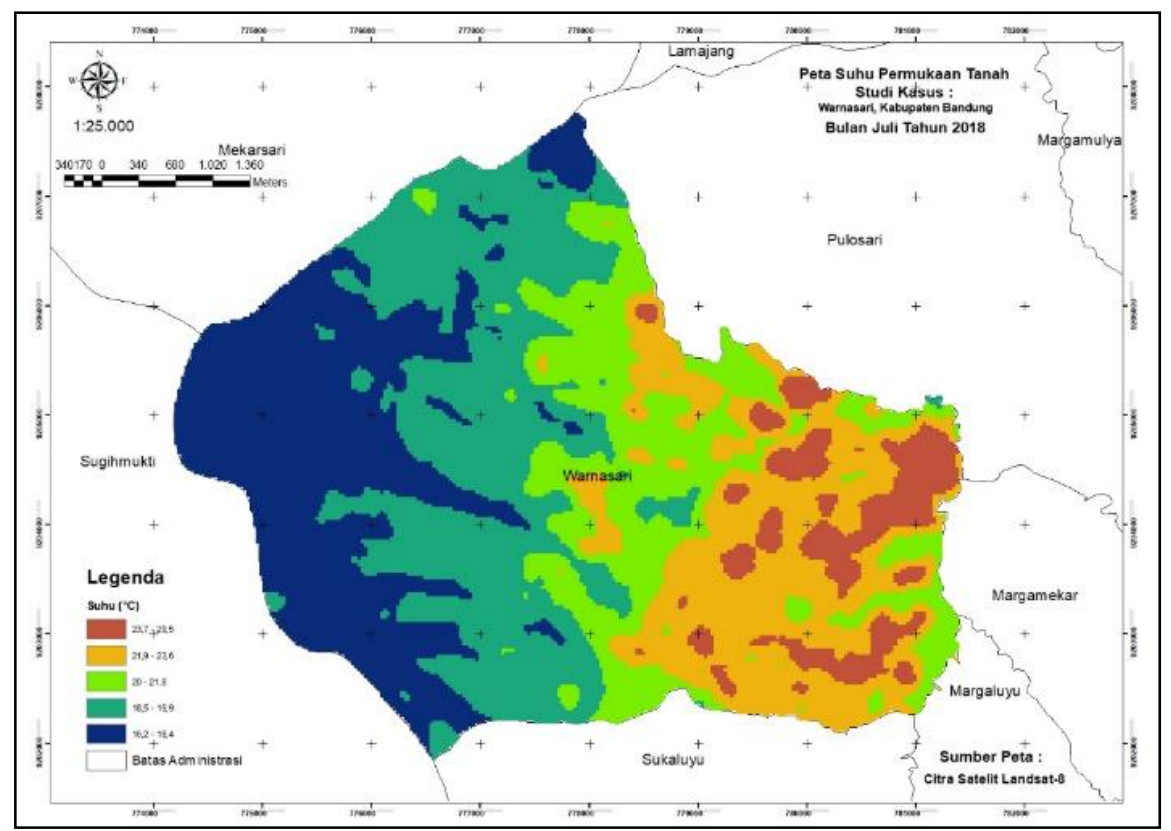

Gambar 14. Peta Suhu Permukaan Tanah Warnasari, Kabupaten Bandung Raya Bulan Juli Tahun 2018 Citra Satelit Landsat-8

Hasil pemetaan suhu permukaan tanah di Wilayah Wargaluyu, Kabupaten Bandung pada bulan April Agustus Tahun 2018 nilai suhu tertinggi terjadi pada bulan Agustus dengan nilai suhu $30,8{ }^{\circ} \mathrm{C}$ dan nilai minimum dengan nilai $21,6^{\circ} \mathrm{C}$ seperti yang ditunjukan pada Gambar 15 .

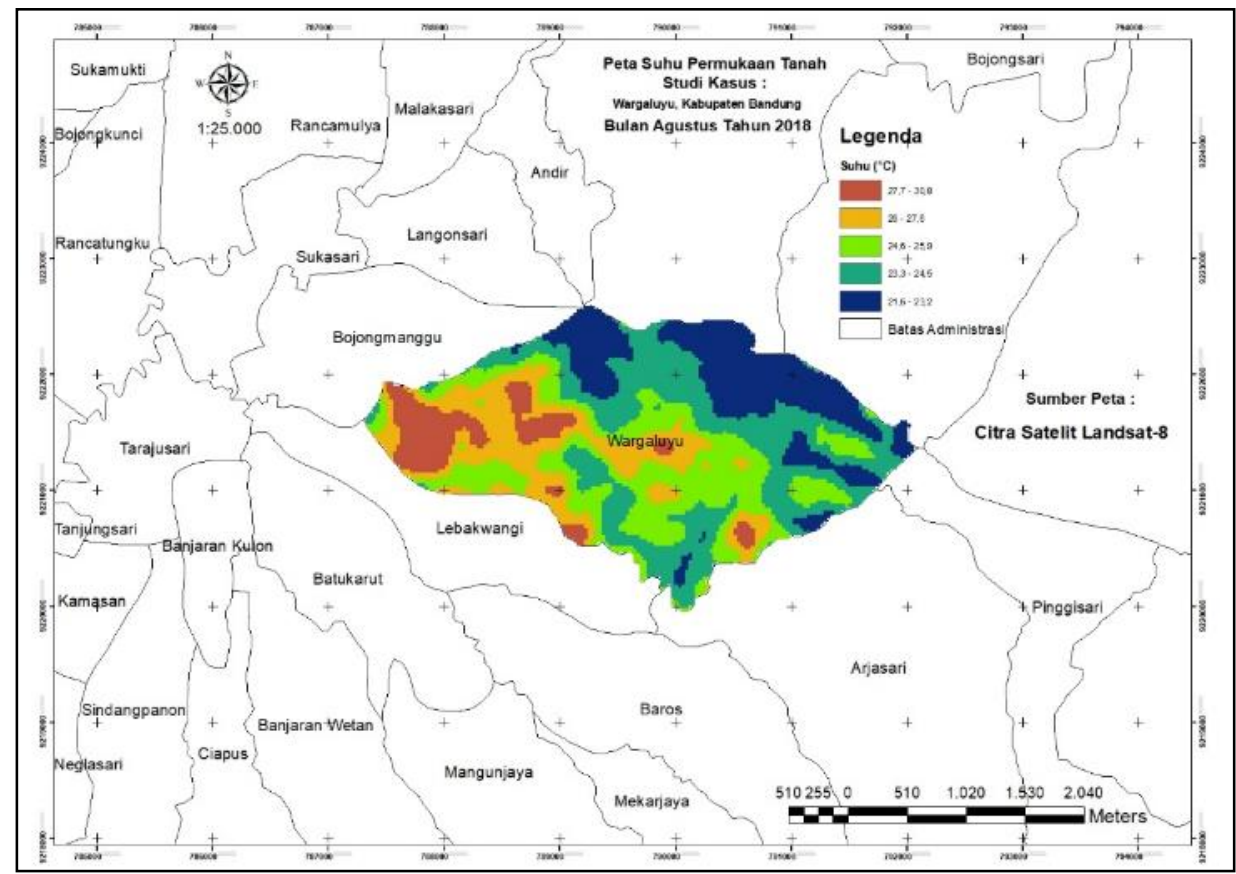

Gambar 15. Peta Suhu Permukaan Tanah Wargaluyu, Kabupaten Bandung Raya Bulan Agustus Tahun 2018 Citra Satelit Landsat-8 
Tabel 2. Nilai Kelembapan Tanah pada wilayah Kabupaten Bandung Raya pada Citra Satelit Sentinel-1A

\begin{tabular}{l|c|c|c|c|c}
\hline \multirow{2}{*}{ Wilayah } & \multirow{3}{*}{ Citra Satelit } & \multirow{2}{*}{ Bulan } & \multicolumn{3}{|c}{$\begin{array}{c}\text { Nilai Kelembapan } \\
\text { tanah Tanah (\%) }\end{array}$} \\
\cline { 3 - 6 } & & & Max & Mean & Min \\
\hline \multirow{4}{*}{$\begin{array}{c}\text { Sentinel 1A } \\
\text { (Polarisasi VH) }\end{array}$} & April & 26 & 20,3 & 11,8 \\
\cline { 3 - 6 } & & Mei & 27 & 20,9 & 11,8 \\
\cline { 3 - 6 } & & Juni & 25,9 & 20,2 & 11,8 \\
\cline { 3 - 6 } & & Juli & 25,9 & 20,2 & 11,8 \\
\cline { 3 - 6 }$(190985,132373$ ha) & & Agustus & 25,8 & 20,2 & 11,8 \\
\cline { 3 - 6 } & \multirow{4}{*}{$\begin{array}{c}\text { Sentinel 1A } \\
\text { (Polarisasi VV) }\end{array}$} & April & 31,2 & 23,4 & 11,8 \\
\cline { 3 - 6 } & & Mei & 78,1 & 51,5 & 11,8 \\
\cline { 3 - 6 } & & Juni & 55,1 & 37,7 & 11,8 \\
\cline { 3 - 6 } & & Juli & 41,2 & 29,4 & 11,8 \\
\cline { 3 - 6 } & & Agustus & 91 & 59,3 & 11,8 \\
\hline
\end{tabular}

Tabel 3. Nilai Suhu Permukaan Tanah pada wilayah Kabupaten Bandung Raya pada Citra Satelit Landsat-8

\begin{tabular}{l|c|c|c|c|c}
\hline \multirow{2}{*}{ Wilayah } & \multirow{2}{*}{ Citra Satelit } & \multirow{2}{*}{ Bulan } & \multicolumn{3}{|c}{ Suhu $\left({ }^{\circ} \mathbf{C}\right)$} \\
\cline { 3 - 6 } & & & Max & Mean & Min \\
\hline \multirow{2}{*}{$\begin{array}{l}\text { Kabupaten } \\
\text { Bandung } \\
(190985,132373 \\
\text { ha) }\end{array}$} & \multirow{4}{*}{ Landsat-8 } & Meil & 36 & 21,6 & 17 \\
\cline { 3 - 6 } & & Juni & 33,1 & 19,5 & 19 \\
\cline { 3 - 6 } & & Juli & 36,1 & 22,1 & 17 \\
\cline { 3 - 6 } & & Agustus & 37,9 & 23,9 & 19 \\
\hline
\end{tabular}

Nilai kelembapan tanah yang diturunkan dari citra satelit Sentinel 1A dari bulan April hingga bulan Agustus dapat dilihat dalam Tabel 2. Dalam penelitian ini, polarisasi yang digunakan sebagai acuan hasil akhir adalah polarisasi VH. Nilai kelembapan tanah tanah dalam polarisasi VH relatif lebih sesuai dengan kondisi di lapangan dibanding dengan kelembapan tanah yang dihasilkan dengan menggunakan polarisasi VV. Pada polarisasi VV, nilai kelembapan tanah pada bulan Agutus mempunyai nilai $91 \%$, kondisi ini tidak wajar. Hasil dari pengamatan dinamika di wilayah Kabupaten Bandung menghasilkan nilai kelembapan tanah tanah dengan nilai tertinggi pada citra sentinel-1A pada polarisasi VV yaitu pada pada Bulan Mei dengan nilai rata-rata kelembapan tanah tanah sebesar $20.9 \%$ yang dapat dilihat dalam Tabel 2. Nilai suhu permukaan tanah di wilayah Kabupaten Bandung Raya pada bulan Mei memiliki nilai suhu rata-rata terendah yaitu sebesar $19.5^{\circ} \mathrm{C}$ seperti yang ditunjukan pada Tabel 3.

Nilai kelembapan tanah dan nilai suhu permukaan tanah pada Kabupaten Bandung Raya dilakukan kolerasi antara kedua nilai tersebut dengan metode koefisien determinasi. Terlihat pada Gambar 16 yaitu kolerasi nilai kelembapan tanah tanah dengan Citra Satelit Sentinel 1-A Polarisasi VH dan suhu permukaan tanah dengan Citra Satelit Landsat-8. 


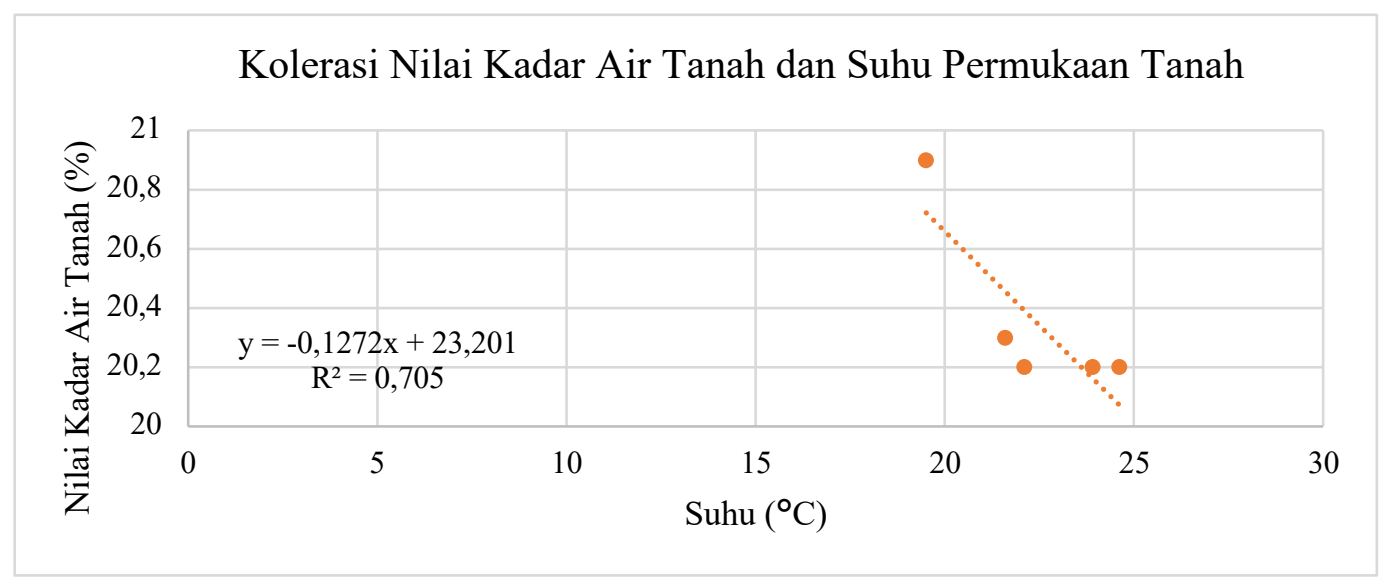

Gambar 16. Regresi Linear antara Nilai Kelembaban pada Citra Satelit Sentinel-1A Polarisasi VH dan Suhu Permukaan Tanah di wilayah Kabupaten Bandung Raya pada Bulan April - Agustus tahun 2018

\section{KESIMPULAN}

Kesimpulan yang dapat diambil dari hasil penelitian sebagai berikut:

1. Kelembapan tanah merupakan air dalam kondisi cair yang menempati ruang-ruang kosong antara partikel tanah, disebut air kapiler. Pengukuran kelembapan tanah yang cepat dan tepat sangat penting untuk berbagai disiplin ilmu bumi. Kelembapan tanah dapat diukur secara in-situ, yang berarti mengukur kelembapan tanah secara langsung ke lapangan, atau menggunakan teknik penginderaan jauh.

2. Pengukuran kelembapan tanah secara langsung ke lapangan tidak praktis dikarenakan membutuhkan waktu yang lama dan biaya yang mahal. Kondisi ini membangkitkan semangat para ilmuwan untuk mengembangkan teknik satelit penginderaan jauh berbasis parameter kelembapan tanah.

3. Penginderaan jauh bisa memecahkan masalah metode tradisional untuk mengukur kelembapan tanah. Pertama, dapat memecahkan masalah pengukuran dari lokasi yang hanya titik per titik. Kedua, peta kelembapan tanah untuk area yang luas dapat di produksi dengan biaya relatif rendah.

4. Polarisasi VH pada citra satelit Sentinel 1A digunakan untuk menurunkan nilai kelembapan tanah dikarenakan nilai kelembapan tanah yang diturunkan menggunakan polarisasi VV terdapat nilai yang tidak sesuai dengan kondisi di lapangan.

5. Pengamatan dinamika pada wilayah Kabupaten Bandung Raya nilai kelembapan tanah tanah tertinggi terjadi pada bulan Mei dengan nilai kelembapan tanah rata-rata sebesar $20.9 \%$ pada polarisasi $\mathrm{VH}$

6. Suhu permukaan tanah terendah terjadi pada bulan Mei dengan nilai suhu rata-rata sebesar $19.5^{\circ} \mathrm{C}$.

7. Kolerasi antara nilai kelembapan tanah tanah dan suhu permukaan tanah pada wilayah Kabupaten Bandung Raya berdasarkan metode koefisien determinasi sebesar $\mathrm{R}^{2=} 0.705$ didapatkan bahwa semakin tinggi nilai kelembapan tanah tanah maka nilai suhu permukaan tanah akan semakin rendah.

Berdasarkan penelitian ini, terdapat beberapa saran terkait dengan pelaksanaan penelitian sebagai berikut:

1. Diperlukan data tambahan seperti data secara langsung (in-situ), parameter pengamatan yang lebih dari satu tahun, yang dapat mendukung proses pengamatan dinamika dan pemetaan kawasan lahan basah lebih baik.

2. Diperlukan teknologi pengindraan jauh yang resolusi lebih tinggi,(resolusi spasial Band lebih panjang (L-Band) dan resolusi temporal 10 hari) dalam pengolahan data baik dari pengindraan jauh optik dan radar, yang dapat dijadikan indeks penggunaan pengolahan kawasan lahan basah. 


\section{DAFTAR PUSTAKA}

[1] Rahmawaty, A. R. and Siregar,A.Z., (2014). "Kajian Sebaran Lahan Gambut sebagai Lahan Padi di Pantai Timur Sumatera Utara", Warta Konservasi Lahan Basah," Balai Penelitian Pertanian Lahan Rawa, vol.11, no.3.

[2] Masganti, Wahyunto, A. Dariah, Nurhayati, and Y. Rachmiwati, (2014). "Karakteristik dan Potensi Pemanfaatan Lahan Gambut Terdegradasi di Provinsi Riau," Badan Litbang Pertanian, vol. 8, no. 1, p. 8 .

[3] Nazemi, D.A. Hairanai, and Indrayati,L., (2012). "Prospek Pengembangan Penataan Lahan Sistem Surjan DI Lahan Rawa Pasang Surut," Agrovigor, vol. 5 No.2, p. 113.

[4] Hardjoamidjojo, S. and Setiawan, B. I., (2001). "Pengembangan Dan Pengelolaan Air di Lahan Basah," Keteknikan Pertanian, vol. 15 No 1.

[5] Schmidt, K. and Skidmore, A., (2002). "Spectral discrimination of vegetation types in a coastal wetland. Remote Sensing of Environment," Remote Sensing of Environment, pp. 92-108.

[6] Guo, A., Li, J., Sheng, C., Xu, J., and Wu, L., (2017)."A Review of Wetland Remote Sensing," Sensors, vol. 17, no. 4, p. 777, doi: 10.3390/s17040777.

[7] Zhang,S., "Identifying wetland change in China's Sanjiang Plain using remote sensing,(2009). " Wetlands, vol. 29, no. 1, pp. 302-313, Mar. 2009, doi: 10.1672/08-04.1.

[8] Gallant,A., (2014). "Detecting Emergence, Growth, and Senescence of Wetland Vegetation with Polarimetric Synthetic Aperture Radar (SAR) Data." Water, vol. 6, no. 3, pp. 694-722, doi: 10.3390/w6030694.

[9] Smith, L. C., (1997)."Satellite remote sensing of river inundation area, stage, and discharge: a review," Hydrological Processes, pp. 1427-1439, 1997.

[10] Borowik,T., Pettorelli, N., Sönnichsen, L. C., and Jędrzejewska, B.(2013). "Normalized difference vegetation index (NDVI) as a predictor of forage availability for ungulates in forest and field habitats." European Journal of Wildlife Research, vol. 59, no. 5, pp. 675-682, doi: 10.1007/s10344013-0720-0. 